\title{
MET FISH-positive status predicts short progression-free survival and overall survival after gefitinib treatment in lung adenocarcinoma with EGFR mutation
}

Rintaro Noro ${ }^{1}$, Masahiro Seike ${ }^{1 *}$, Fenfei Zou', Chie Soeno ${ }^{1}$, Kuniko Matsuda', Teppei Sugano ${ }^{1}$, Nobuhiko Nishijima', Masaru Matsumoto ${ }^{1}$, Kazuhiro Kitamura ${ }^{1}$, Seiji Kosaihira ${ }^{1}$, Yuji Minegishi ${ }^{1}$, Akinobu Yoshimura ${ }^{2}$, Kaoru Kubota ${ }^{1}$ and Akihiko Gemma'

\begin{abstract}
Background: Lung adenocarcinoma patients with EGFR gene mutations have shown a dramatic response to gefitinib. However, drug resistance eventually emerges which limits the mean duration of response. With that in view, we examined the correlations between MET gene status as assessed by fluorescence in situ hybridization (FISH) with overall survival (OS) and progression-free survival (PFS) in adenocarcinoma patients with EGFR gene mutations who had received gefitinib therapy.

Methods: We evaluated 35 lung cancer samples with EGFR mutation from adenocarcinoma patients who had received gefitinib. Gene copy numbers (GCNs) and amplification of MET gene before gefitinib therapy was examined by FISH. MET protein expression was also evaluated by immunohistochemistry (IHC).
\end{abstract}

Results: FISH assessment showed that of the 35 adenocarcinoma samples, 10 patients (29\%) exhibited high

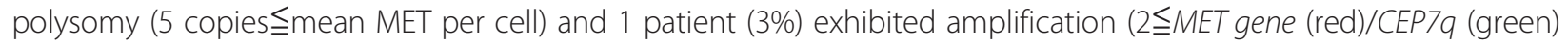
per cell). IHC evaluation of MET protein expression could not confirm MET high polysomy status. The Eleven patients with MET FISH positivity had significantly shorter progression-free survival (PFS) and overall survival (OS) than the 24 patients who were MET FISH-negative (PFS: $p=0.001$ and OS: $p=0.03$ ). Median PFS and OS with MET FISH-positivity were 7.6 months and 16.8 months, respectively, whereas PFS and OS with MET FISH-negativity were 15.9 months and 33.0 months, respectively. Univariate analysis revealed that MET FISH-positivity was the most significant independent factor associated with a high risk of progression and death (hazard ratio, $3.83(p=0.0008)$ and 2.25 ( $p=0.03)$, respectively).

Conclusions: Using FISH analysis to detect high polysomy and amplification of MET gene may be useful in predicting shortened PFS and OS after Gefitinib treatment in lung adenocarcinoma. The correlation between MET gene status and clinical outcomes for EGFR-TKI should be further evaluated using large scale samples.

Keyword: MET, Lung cancer, Fluorescence in situ hybridization, Gefitinib, EGFR mutation

\footnotetext{
* Correspondence: mseike@nms.ac.jp

${ }^{1}$ Department of Pulmonary Medicine and Oncology, Graduate School of Medicine, Nippon Medical School, Tokyo, Japan

Full list of author information is available at the end of the article
} 


\section{Background}

Activating mutations of the epidermal growth factor receptor $(E G F R)$ gene, including the deletion mutations around nucleotide residue 746-750 in exon 19 (exon 19 deletion) and also substitution of leucine with arginine at codon 858 in exon 21 (exon 21 L858R), are correlated with sensitivity to EGFR-tyrosine kinase inhibitors (EGFRTKIs) [1,2]. Approximately $80 \%$ of activating EGFR mutant cases shows a dramatic response to EGFR-TKIs [3]. In recent phase III trials of the EGFR-TKI, gefitinib, demonstrated a significant superiority on progression-free survival (PFS) over standard chemotherapies as the first-line treatment for EGFR-mutated advanced non-small cell lung cancer (NSCLC) $[4,5]$. However, despite of the existence of EGFR gene activating mutations, the mean duration of many patients' successful response to gefitinib is shortened as they acquire drug resistance. Mechanisms of acquired resistance to EGFR-TKI have recently been found, such as T790M secondary mutation and $M E T$ amplification [6,7].

$M E T$ amplification is recognized as one of the acquired mechanisms of resistance to EGFR-TKIs [7]. Although MET activation is relatively rare in patients with EGFR mutations before EGFR-TKI treatments, MET gene amplification based on clonal selection later appears at the relapse stage [8]. A recent report demonstrated that $M E T$ gene activation as assessed by fluorescence in situ hybridization (FISH) analysis contributed to poor prognosis in NSCLC patients who received surgical treatments [9]. Though it is very difficult to predict resistance to EGFR-TKI before EGFR-TKI therapy and then PFS and OS after EGFR-TKI treatment because of $M E T$ gene activation, there may still be a substantial clinical benefit for assessing MET FISH status in NSCLC patients with EGFR gene mutations especially before initiation of EGFR-TKI therapy.

In this study, we investigated if $M E T$ gene copy number status as assessed by FISH could predict the clinical outcome for EGFR-TKI in EGFR-mutated lung adenocarcinoma patients.

\section{Methods}

\section{Patients and clinical features}

Thirty-five tumor specimens with EGFR gene mutations were obtained from 35 lung adenocarcinoma patients, all of whom had received gefitinib and provided written informed consent, at Nippon Medical School Hospital between 2008 and 2010 (Table 1). Tumor samples were obtained by resections, aspirated pleural/cardiac effusion, and transbronchial lung biopsies. Patients' characteristics are shown in Table 1. Seventeen patients had relapses despite complete tumor resection. Eighteen patients had stage III and IV cancers according to the World Health Organization TNM staging $7^{\text {th }}$ Edition. Response to gefitinib was evaluated by Response Evaluation Criteria in
Solid Tumors (RECIST) version 1.0. This study was approved by Nippon Medical School Hospital's Institutional Review Board. Every patient has a signature of informed consent.

\section{EGFR mutation analysis}

Cytologic or histologic specimens were examined for EGFR mutations by the PNA-LNA PCR clamp method as reported previously [10].

\section{Fluorescence in situ hybridization (FISH)}

Gene copy numbers (GCNs) and amplification of $M E T$ gene were examined by FISH. The tissue sections were then hybridized with Met (TexRed)/CEN7q (FITC) Dual Color FISH Probe. (GSP Laboratory, LCI Medience Corporation, Chiba, Japan). The number of fluorescence signals was counted independently by two investigators using an Axio Vision microscope (Carl Zeiss, Oberkochen, Germany). MET GCN was determined by FISH with probes for Met (TexRed)/CEN7q (FITC) Dual Color FISH Probe. FISH positivity was estimated using the standard Colorado criteria (gene amplification; $2 \leqq M E T$ gene (red)/CEP7q (green) per cell plus high polysomy; 5 copies $\leqq$ mean MET per cell) [9,11-13] (Figure 1).

\section{Immunohistochemical (IHC) analysis}

For IHC of MET, formalin-fixed paraffin-embedded tissue sections were stained by the immunoperoxidase method with avidin-biotin complex as described previously [14]. The slides were incubated with a primary antibody against MET, clone SP44 (1:50, Spring Bioscience, Pleasanton, CA). Positive is defined as the membranous and/or cytoplasmic staining in greater than $10 \%$ tumor cells with moderate level and high level. Negative is defined as the membranous and/or cytoplasmic staining less than 10\% tumor cells and the membranous and/or cytoplasmic staining in greater than $10 \%$ tumor cells with low level. [14] (Figure 1D-F).

\section{Statistical analyses}

Correlations between response rate and clinical characteristics were compared by Fisher's exact test. Progressionfree survival (PFS) was calculated from the time of gefitinib therapy to time of disease progression or last disease assessment. Overall survival (OS) was calculated from the time of gefitinib therapy to patient death or last contact. Kaplan-Meier survival curves were drawn for PFS and OS and compared by log-rank test. Univariate and multivariate analyses were performed using the Cox regression model. Statistical significance was defined as $\mathrm{p}<$ 0.05 for each analysis. All statistical analyses were carried out using Stat Flex version 7 [11]. 
Table 1 EGFR and MET gene status of 35 lung adenocarcinoma cases

\begin{tabular}{|c|c|c|c|c|c|c|c|c|c|c|}
\hline \multirow[b]{2}{*}{$\begin{array}{l}\text { Case } \\
\mathrm{No}^{\mathrm{b}}\end{array}$} & \multirow[b]{2}{*}{ Smoking } & \multirow[b]{2}{*}{ Staging } & \multirow[b]{2}{*}{$\begin{array}{l}\text { Gefitinib } \\
\text { response }\end{array}$} & \multirow[b]{2}{*}{$\begin{array}{l}\text { EGFR mutation } \\
\text { type }\end{array}$} & \multirow[b]{2}{*}{ MET FISH status } & \multicolumn{2}{|c|}{$\begin{array}{l}\text { Before Gefitinib } \\
\text { treatments }\end{array}$} & \multirow[b]{2}{*}{$\begin{array}{l}\text { MET FISH } \\
\text { status }\end{array}$} & \multicolumn{2}{|c|}{$\begin{array}{l}\text { At Gefitinib } \\
\text { treatment failure }\end{array}$} \\
\hline & & & & & & $\begin{array}{l}\text { MET } \\
\text { IHC }\end{array}$ & $\begin{array}{l}\text { EGFR mutation } \\
\text { type }\end{array}$ & & PFS(Months) & OS(Months) \\
\hline 1 & - & IV & $P R$ & Ex19 deletion & ++ & + & Ex19 deletion & ++ & 7.3 & 15 \\
\hline 2 & - & IV & PR & Ex19 deletion & + & & Not detected & + & 7.6 & 11.9 \\
\hline 3 & + & Relapse & PR & Ex19 deletion & + & & Ex19 deletion/T790M & + & 18.5 & 34.4 \\
\hline 4 & - & Relapse & $P R$ & Ex19 deletion & + & - & & & 16.6 & 20.9 \\
\hline 5 & + & $\| \mathrm{A}$ & PR & Ex19 deletion & + & & & & 8.5 & 20 \\
\hline 6 & - & Relapse & $P R$ & Ex19 deletion & + & & & & 1.8 & 1.8 \\
\hline 7 & - & IV & PD & $L 858 R$ & + & & $L 858 R$ & + & 13.6 & 15 \\
\hline 8 & + & Relapse & PD & L858R & + & + & & & 2.7 & 8.8 \\
\hline 9 & - & Relapse & $C R$ & $L 858 R$ & + & - & & & 13 & 28.4 \\
\hline 10 & - & Relapse & $P R$ & $L 858 R$ & + & - & & & 7.6 & 11.2 \\
\hline 11 & + & IV & $P R$ & $L 858 R$ & + & & & & 5.7 & 7.3 \\
\hline 12 & + & IV & PR & Ex19 deletion & - & & Ex19 deletion & - & 13.9 & 21 \\
\hline 13 & + & IV & PR & Ex19 deletion & - & & Ex19 deletion & - & 10.4 & 36.4 \\
\hline 14 & - & IV & $P R$ & Ex19 deletion & - & & Ex19 deletion & - & 24.7 & 31.1 \\
\hline 15 & - & Relapse & $P R$ & Ex19 deletion & - & - & Ex19 deletion/T790M & - & 28.4 & 33.8 \\
\hline 16 & - & Relapse & PR & Ex19 deletion & - & - & & & 11.1 & 21 \\
\hline 17 & + & Relapse & $P R$ & Ex19 deletion & - & - & & & 24.4 & 24.4 \\
\hline 18 & - & $\| \mathrm{A}$ & $P R$ & Ex19 deletion & - & & & & 6.5 & 14.9 \\
\hline 19 & - & $\| \mathrm{IIB}$ & $P R$ & Ex19 deletion & - & & & & 29.8 & 38.2 \\
\hline 20 & + & $\| \mathrm{IIB}$ & PR & Ex19 deletion & - & & & & 41.5 & 48.6 \\
\hline 21 & - & IV & $P R$ & Ex19 deletion & - & & & & 13.2 & 26.7 \\
\hline 22 & + & IV & $P R$ & Ex19 deletion & - & & & & 17.1 & 17.1 \\
\hline 23 & - & IV & PR & Ex19 deletion & - & & & & 13.3 & 19.2 \\
\hline 24 & - & IV & PR & Ex19 deletion & - & & & & 21.8 & 25.5 \\
\hline 25 & - & IV & PR & Ex19 deletion & - & & & & 15.2 & 31.6 \\
\hline 26 & - & IV & SD & Ex19 deletion & - & & & & 3.4 & 26.8 \\
\hline 27 & + & Relapse & $P R$ & Ex19 deletion & - & & & & 18.7 & 50.2 \\
\hline 28 & + & Relapse & PR & Ex19 deletion & - & & & & 15.9 & 20.2 \\
\hline 29 & - & Relapse & PR & Ex19 deletion & - & & & & 12.1 & 15 \\
\hline 30 & + & Relapse & SD & Ex19 deletion & - & & & & 11.1 & 13.6 \\
\hline 31 & - & Relapse & PR & $L 858 R$ & - & & $L 858 R$ & - & 58.7 & 123.5 \\
\hline 32 & - & IV & $P R$ & $L 858 R$ & - & - & & & 4.5 & 4.5 \\
\hline 33 & + & Relapse & $P R$ & L858R & - & & & & 15.5 & 16.7 \\
\hline 34 & + & Relapse & $P R$ & L858R & - & & & & 13.5 & 13.5 \\
\hline 35 & - & Relapse & PR & $L 858 R$ & - & & & & 7.1 & 7.1 \\
\hline
\end{tabular}

MET FISH status; ++Amplification, +High polysomy.

${ }^{\mathrm{b}}$ Patient identifiers have been removed and relabeled.

\section{Results}

Status of EGFR and MET genes before gefitinib therapy and at treatment failure

Eleven of 35 patients (31\%) had MET gene activation as estimated by FISH analysis. High polysomy was observed in 10 patients (29\%) and amplification was in 1 patient (3\%) of 11 MET FISH-positive cases (Table 1) (Figure 1A-C). Nine cases were available for evaluation of EGFR and MET status by FISH at the failure of gefitinib therapy (Table 1). T790M secondary mutation was detected in 2 of 9 patients examined at gefitinib treatment failure (cases 3, 15). Exon 19 deletion was not detected at gefitinib failure in one case 

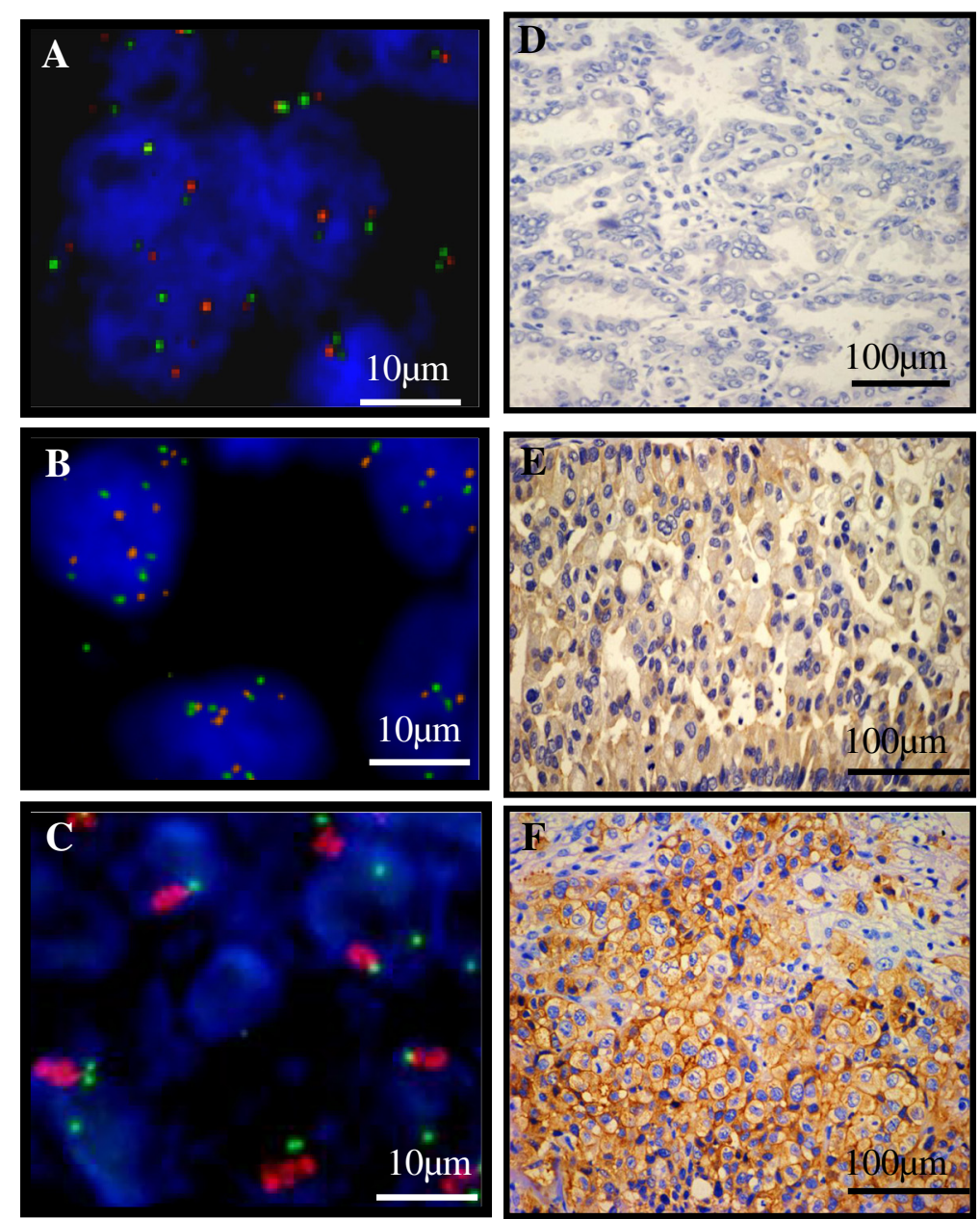

Figure 1 FISH analysis of the MET gene and immunohistochemical staining for MET protein. Gene copy numbers (GCNs) and amplification of the MET gene were examined by fluorescence in situ hybridization (FISH). (A) FISH negativity was defined as mean MET per cell $<5$ copies. (B) High polysomy was defined as 5 copies $\leqq$ mean MET per cell. (C) Amplification was defined as $2 \leqq M E T$ gene (red)/CEP7q (green) per cell. FISH positivity consisted of high polysomy and amplification. (D) Low level of MET protein expression in lung adenocarcinoma tissues. (E) Moderate level of MET protein expression in lung adenocarcinoma tissues. (F) High level of MET protein expression in lung adenocarcinoma tissues. Bars indicate $100 \mu \mathrm{m}$.

(case 2). Four cases were also observed to be MET FISH-positive at the failure of gefitinib treatment (cases $1,2,3,7)$. One case with $M E T$ amplification before initiation of therapy was also found to harbor amplification during relapse (case 1). At gefitinib failure, coexistence of T790M and MET high polysomy of the MET gene were observed in one case (case 3). MET gene status was found to be not related to clinicopathological factors (Table 2).

\section{Relationship between GCNs and MET protein expression}

Next, we assessed MET protein expression levels in 9 available tumor sections by IHC and evaluated the relationship between the expression of MET and GCNs (Table 1) (Figure 1D-F). One case with MET amplification showed high MET protein expression (case 1), and correspondingly, no positive MET staining was observed in the 4 patients without high polysomy (cases 15, 16, 17,32 ). However, only one of four cases with high polysomy showed moderate level of MET expression (case 8). One limitation of our study was that the number of samples was small. Thus, analysis of MET protein expression by IHC could not confirm MET high polysomy status.

\section{Correlation between EGFR gene and gefitinib sensitivity} 3000The EGFR gene mutation subtype was not found to be associated with sensitivity to gefitinib. Median PFS of patients harboring the L858R and exon 19 deletion mutations was 14.6 months and 13.1 months, respectively $(p=0.78)$ (Figure 2A). Median OS of patients harboring the L858R and exon 19 deletion mutations was 15.3 months and 31.1 months, respectively ( $p=0.29)$ (Figure 2B). 
Table 2 Clinicopathologic characteristics of the 35 lung adenocarcinoma cases

\begin{tabular}{|c|c|c|c|c|c|c|c|}
\hline & \multirow[b]{3}{*}{ Total } & \multirow[b]{3}{*}{$\%$} & \multicolumn{4}{|c|}{ MET gene FISH status } & \multirow{3}{*}{$\mathrm{p}$-value } \\
\hline & & & \multicolumn{2}{|c|}{ FISH-negative } & \multicolumn{2}{|c|}{ FISH-positive } & \\
\hline & & & Total & $\%$ & Total & $\%$ & \\
\hline Variables & 35 & 100 & 24 & 100 & $11^{a}$ & 100 & \\
\hline \multicolumn{8}{|l|}{ Age } \\
\hline$<65$ & 13 & 37 & 9 & 38 & 4 & 36 & \\
\hline $65 \leqq$ & 22 & 63 & 15 & 63 & 7 & 64 & 1.00 \\
\hline \multicolumn{8}{|l|}{ Gender } \\
\hline Male & 15 & 43 & 12 & 50 & 3 & 27 & \\
\hline Female & 20 & 57 & 12 & 50 & 8 & 73 & 0.28 \\
\hline \multicolumn{8}{|l|}{ Smoking status } \\
\hline Current and former smoker & 14 & 40 & 10 & 42 & 4 & 36 & \\
\hline Never smoker & 21 & 60 & 14 & 58 & 7 & 63 & 1.00 \\
\hline \multicolumn{8}{|l|}{ Stage } \\
\hline III & 4 & 11 & 3 & 13 & 1 & 9 & \\
\hline IV + Relapse & 31 & 89 & 21 & 87 & 10 & 91 & 1.00 \\
\hline \multicolumn{8}{|l|}{ EGFR mutation subtype } \\
\hline Exon19 deletion & 25 & 71 & 19 & 79 & 6 & 55 & \\
\hline Exon 21 L858R & 10 & 29 & 5 & 21 & 5 & 46 & 0.23 \\
\hline \multicolumn{8}{|l|}{ Response to Gefitinib } \\
\hline$C R+P R$ & 31 & 89 & 22 & 92 & 9 & 82 & \\
\hline $\mathrm{SD}+\mathrm{PD}$ & 4 & 11 & 2 & 8 & 2 & 18 & 0.57 \\
\hline
\end{tabular}

${ }^{a}$ High polysomy was observed in 10 patients (28.5\%) and amplification was in 1 patients (2.9\%) of 35 NSCLC patients.

Correlation between MET gene status, EGFR-TKI sensitivity, PFS and OS after gefitinib treatment

Responses to gefitinib were not significantly different according to MET gene status (Table 2). However, PFS in $M E T$ FISH-positive patients was significantly shorter than in MET FISH-negative patients. Median PFS in MET FISHnegative and MET FISH-positive patients was 15.9 months and 7.6 months, respectively $(\mathrm{p}=0.001)$ (Figure $3 \mathrm{~A})$. One case with MET gene amplification had PR with shorter PFS at 7.3 months (case 1) (Table 1). Furthermore, median OS in $M E T$ FISH-negative and MET FISH-positive patients was 33.0 months and 16.8 months, respectively (Figure 3B), and the difference in OS between these cases was statistically significant $(\mathrm{p}=0.03)$. Univariate Cox regression analysis revealed that MET FISH-positive cases showed a significantly poorer outcome than negative cases (hazard ratio for progression and death in MET FISH-positive cases relative to MET FISH-negative cases, 3.83 $(\mathrm{p}=0.008)$ and $2.25(\mathrm{p}=0.03)$, respectively (Table 3$)$.

\section{Discussion}

In this study, we evaluated by FISH analyses, the $M E T$ status of 35 lung adenocarcinoma patients with EGFR gene mutations who received gefitinib therapy. MET gene amplification before EGFR-TKI therapy was observed by high-throughput FISH analysis [8]. This finding suggests that possibly a small population of cancer cells with $M E T$ gene amplification can become major clones after EGFR-TKI treatment and upon accumulation of secondary genetic alterations, such as the T790M mutation. In our analysis, MET FISH-positivity was also detected after continued exposure to gefitinib. Of course MET status is only one of several molecular mechanisms that account for resistance to TKIs, and was the only one we investigated in the 35 cases. Other mechanisms could lead to acquiring drug resistance. For example, it is possible that many more of the relapsed, non-tested, cases carried T790M mutations and that this was greater factor shortening the survival rate in the few MET positives cases.

A recent report demonstrated that lung adenocarcinoma cases with a co-existence of positive MET FISH status and EGFR mutation had shorter disease-free survival (DFS) as well as OS after resection [15]. However, the relationship between $M E T$ FISH status and clinical outcomes of treatment with EGFR-TKIs has not been 


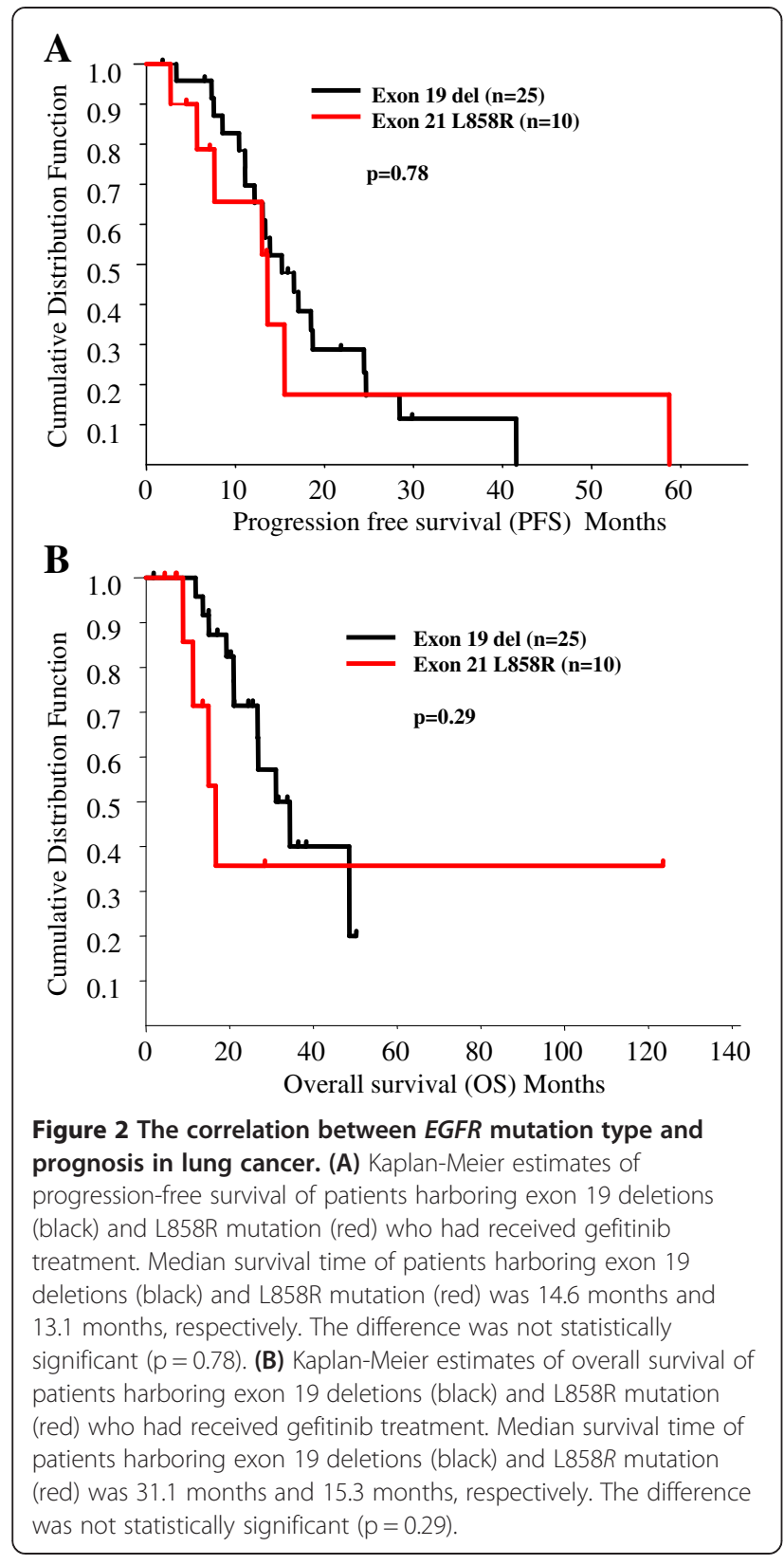

evaluated in previous reports $[15,16]$. Our data showed that the response to gefitinib was not significantly different according to $M E T$ gene status. Nevertheless, $M E T$ FISH-positive patients revealed not only significantly shorter PFS but also OS from the beginning of gefitinib therapy as compared to MET FISH-negative patients. Previous reports demonstrated that gain of MET GCNs may be related to the elevation of MET protein expression and its phosphorylation [17]. In this study, FISH amplification patients had high MET protein expression. However, MET high polysomy status could not be verified by IHC. More samples will be

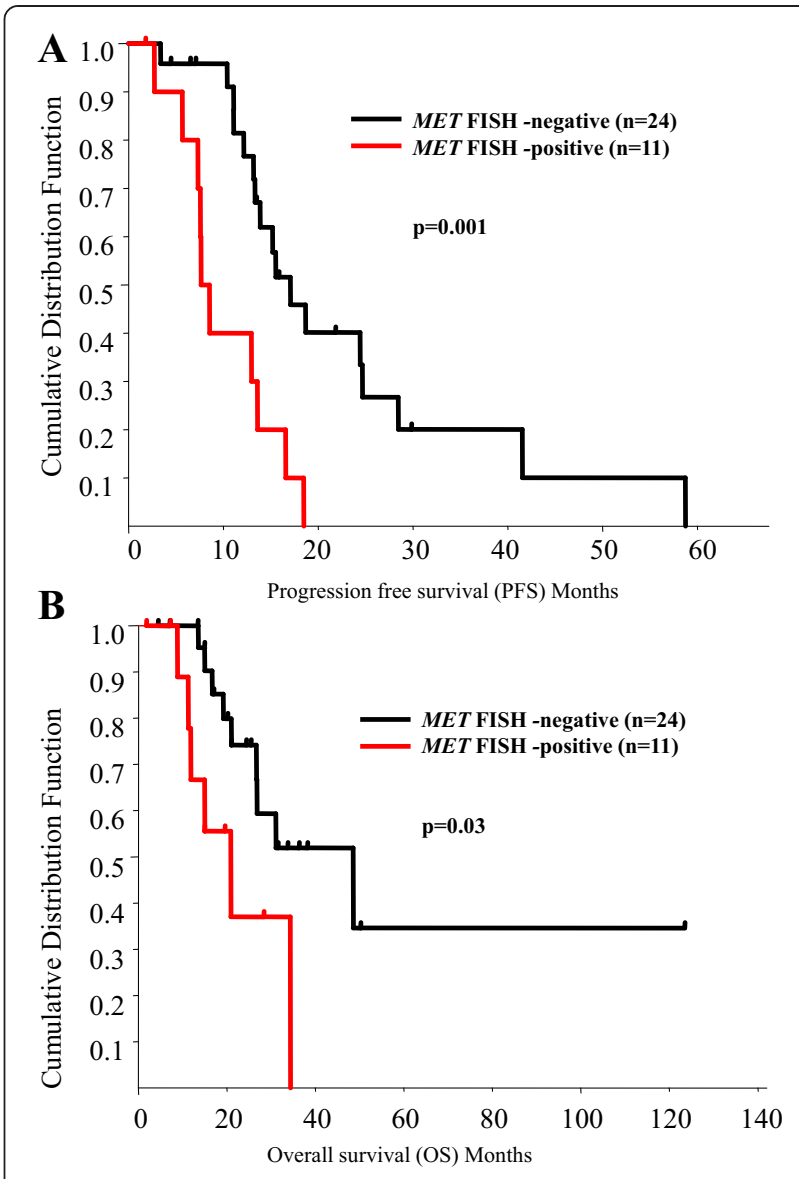

Figure 3 Prognostic significance of MET FISH-positivity in lung cancer. (A) Kaplan-Meier estimates of progression-free survival of FISH-negative (black) and -positive (red) patients who had received gefitinib treatment. Median survival time of FISH-negative (black) and -positive (red) patients was 15.9 months and 7.6 months, respectively. The difference was statistically significant $(p=0.001)$. (B) Kaplan-Meier estimates of overall survival of FISH-negative (black) and -positive (red) patients who had received gefitinib treatment. Median survival time of FISH-negative (black) and -positive (red) patients was 33.0 months and 16.8 months, respectively. The difference was statistically significant $(p=0.03)$.

needed for evaluating the correlation between MET GCNs and MET protein expression. These results suggest that detection of high polysomy and amplification of $M E T$ gene by FISH may be useful for predicting short PFS and OS after gefitinib treatment in Lung Adenocarcinoma with EGFR mutation.

Transgenic mouse models for lung cancer that express EGFR mutation with MET overexpression demonstrated that monotherapy targeting either EGFR or MET did not show tumor regression [17]. In contrast, combination therapies targeting both EGFR and MET simultaneously were significantly effective against EGFR TKI-resistant tumors with mutant EGFR and MET activation [18]. Demonstrating this, a recent phase II study 
Table 3 Univariate Cox proportional hazards models of factors associated with death and progression for all cases Hazard ratios for death in according to prognostic factors

\begin{tabular}{|c|c|c|c|c|}
\hline \multirow{2}{*}{$\begin{array}{l}\text { Characteristics } \\
\text { Age }\end{array}$} & \multirow{2}{*}{$\begin{array}{l}\text { Comparison } \\
<65 \text { yr vs. } \geq 65 \mathrm{yr}\end{array}$} & \multicolumn{2}{|c|}{ Hazard ratio $\left[95 \% \mathrm{Cl}^{\mathrm{a}}\right]$} & \multirow{2}{*}{$\begin{array}{l}P \text { value } \\
0.62\end{array}$} \\
\hline & & 1.26 & {$[0.50-3.17]$} & \\
\hline Gender & Female vs. Male & 0.59 & {$[0.23-1.49]$} & 0.27 \\
\hline Smoking status & Never smoker vs. Ever smoker & 0.41 & {$[0.15-1.13]$} & 0.08 \\
\hline Stage & III vs. IV/Relapse & 1.46 & {$[0.34-6.37]$} & 0.61 \\
\hline EGFR mutation type & Exon19 deletion vs. Exon 21 L858R & 1.90 & {$[0.72-5.00]$} & 0.62 \\
\hline MET FISH & Negative vs. Positive & 2.25 & {$[1.07-4.74]$} & 0.03 \\
\hline \multicolumn{5}{|c|}{ Hazard ratios for progression in according to prognostic factors } \\
\hline Characteristics & Comparison & \multicolumn{2}{|c|}{ Hazard ratio $\left[95 \% \mathrm{Cl}^{\mathrm{a}}\right]$} & $P$ value \\
\hline Age & $<65$ yr vs. $\geq 65$ yr & 0.52 & {$[0.23-1.15]$} & 0.11 \\
\hline Gender & Female vs. Male & 0.88 & {$[0.40-1.93]$} & 0.75 \\
\hline Smoking stutus & Never smoker vs. Ever smoker & 1.11 & {$[0.51-2.42]$} & 0.79 \\
\hline Stage & III vs. IV/Relapse & 1.04 & {$[0.30-3.64]$} & 0.95 \\
\hline EGFR mutation type & Exon19 deletion vs. Exon 21 L858R & 1.15 & {$[0.45-2.91]$} & 0.77 \\
\hline MET FISH & Negative vs. Positive & 3.83 & {$[1.75-8.38]$} & 0.0008 \\
\hline
\end{tabular}

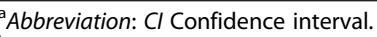

${ }^{\mathrm{b}}$ Cox regression analysis. $\mathrm{P}$ values of $<.05$ are shown in bold.

showed that previously-treated NSCLC patients using a combination therapy of OAM4558g (MET-MAb) plus erlotinib versus just erlotinib alone reported that the MET-MAb plus erlotinib therapy significantly improved PFS and OS, resulting in a near 3-fold reduction in the risk of death. This benefit was observed in patients with MET activation, as evaluated by IHC [19]. However in the Phase III trials, when those patients selected for high MET expression were treated OAM4558g added to erlotinib, it was shown to be not superior to erlotinib alone [20]. In light of this, analyses of EGFR-TKI failing with EGFR mutant cases will be required.

Yet another phase II study with combination therapy in previously-treated NSCLC patients, this one with erlotinib plus tivantinib (ARQ 197) (MET-TKI) versus just erlotinib alone in previously-treated NSCLC patients showed that the median PFS was longer in the erlotinib plus tivantinib group than in the erlotinib alone group, particularly among patients with KRAS mutations, although this study did not meet its primary end point [21]. Based on these phase II trials, additional phase II trials of erlotinib plus tivantinib for EGFR-mutated NSCLC patients after failure of EGFR-TKI treatment are now ongoing in Asian countries. A MET inhibitor combined with EGFR-TKI may be effective in MET FISH-positive patients with EGFR mutations.

\section{Conclusions}

Pre-gefitinib MET FISH status may be useful for predicting PFS and OS after Gefitinib treatment in lung adenocarcinoma with EGFR mutation and for selecting the patients who would benefit from EGFR-TKI and MET inhibitor therapy. Correlations between $M E T$ gene status and clinical outcome for EGFR-TKI should be further evaluated using larger scale samples.

\section{Competing interests}

A.G. had previously obtained the grants from Astrazeneca.

However there are no financial or other interests with regard to the submitted manuscript that might be construed as a conflict of interest.

\section{Authors' contributions}

Manuscript writing: RN and MS. Study design: RN and MS. FISH analyses and IHC analyses: RN, CS and FZ. The collection of clinical samples and data: RN, KM, TS, NN, MM, KK, SK, YM, AY and KK. Statistical analysis: RN and MS. Editing manuscript: RN, MS and AG. Supervised the entire project: MS and AG. All authors read and approved the final manuscript.

\section{Acknowledgements}

We thank Ms. Kumiko Hayashi of LCl Medience Corporation (Chiba, Japan) for her excellent technical assistance. This study was supported in part by a Grant-in-Aid from the Ministry of Education, Culture, Sports, Science, and Technology of Japan (grant no. 25461172 to A. Gemma), and Clinical Rebiopsy Bank Project for Comprehensive Cancer Therapy Development (to M. Seike. and A. Gemma).

\section{Author details}

${ }^{1}$ Department of Pulmonary Medicine and Oncology, Graduate School of Medicine, Nippon Medical School, Tokyo, Japan. ${ }^{2}$ Department of Clinical Oncology, Tokyo Medical University Hospital, Tokyo, Japan.

Received: 13 May 2014 Accepted: 13 January 2015

Published online: 06 February 2015

\section{References}

1. Lynch TJ, Bell DW, Sordella R, Gurubhagavatula S, Okimoto RA, Brannigan BW, et al. Activating mutations in the epidermal growth factor receptor 
underlying responsiveness of non-small-cell lung cancer to gefitinib. New Engl J Med. 2004;350(21):2129-39.

2. Paez JG, Janne PA, Lee JC, Tracy S, Greulich H, Gabriel S, et al. EGFR mutations in lung cancer: correlation with clinical response to gefitinib therapy. Science. 2004;304(5676):1497-500.

3. Mitsudomi T, Yatabe Y. Mutations of the epidermal growth factor receptor gene and related genes as determinants of epidermal growth factor receptor tyrosine kinase inhibitors sensitivity in lung cancer. Cancer Sci. 2007;98(12):1817-24.

4. Maemondo M, Inoue A, Kobayashi K, Sugawara S, Oizumi S, Isobe H, et al. Gefitinib or chemotherapy for non-small-cell lung cancer with mutated EGFR. New Engl J Med. 2010;362(25):2380-8.

5. Mitsudomi T, Morita S, Yatabe Y, Negoro S, Okamoto I, Tsurutani J, et al. Gefitinib versus cisplatin plus docetaxel in patients with non-small-cell lung cancer harbouring mutations of the epidermal growth factor receptor (WJTOG3405): an open label, randomised phase 3 trial. Lancet Oncol. 2010;11(2):121-8.

6. Kobayashi S, Boggon TJ, Dayaram T, Jänne PA, Kocher $\mathrm{O}$, Meyerson M, et al. EGFR mutation and resistance of non-small-cell lung cancer to gefitinib. N Engl J Med. 2005;352(8):786-92. 24.

7. Engelman JA, Zejnullahu K, Mitsudomi T, Song Y, Hyland C, Park JO, et al. MET amplification leads to gefitinib resistance in lung cancer by activating ERBB3 signaling. Science. 2007;316:1039-43.

8. Alexa BT, Kreshnik Z, Yi-Long W, Song Y, Dias-Santagata D, Lifshits E, et al. Preexistence and clonal selection of MET amplification in EGFR mutant NSCLC. Cancer Cell. 2010;17:77-88.

9. Cappuzzo F, Marchetti A, Skokan M, Rossi E, Gajapathy S, Felicioni L, et al. Increased MET gene copy number negatively affects survival of surgically resected non-small-cell lung cancer patients. J Clin Oncol. 2009;27(10):1667-74

10. Nagai Y, Miyazawa H, Huqun, Tanaka T, Udagawa K, Kato M, et al. Genetic heterogeneity of the epidermal growth factor receptor in non-small cell lung cancer cell lines revealed by a rapid and sensitive detection system, the peptide nucleic acid-locked nucleic acid PCR clamp. Cancer Res. 2005;65(16):7276-82.

11. Noro R, Honda K, Tsuta K, Ishii G, Maeshima AM, Miura N, et al. Distinct outcome of stage I lung adenocarcinoma with ACTN4 cell motility gene amplification. Ann Oncol. 2013;24(10):2594-600.

12. Park S, Choi YL, Sung CO, An J, Seo J, Ahn MJ, et al. High MET copy number and MET overexpression: poor outcome in non-small cell lung cancer patients. Histol Histopathol. 2012;27(2):197-207.

13. Cappuzzo F, Hirsch FR, Rossi E, Bartolini S, Ceresoli GL, Bemis L, et al. Epidermal growth factor receptor gene and protein and gefitinib sensitivity in non-small-cell lung cancer. J Natl Cancer Inst. 2005;97(9):643-55.

14. Tsuta K, Kozu Y, Mimae T, Yoshida A, Kohno T, Sekine I, et al. c-MET/ Phospho-MET protein expression and MET gene copy number in non-small cell lung carcinomas. J Thorac Oncol. 2012;7(2):331-9.

15. Tanaka A, Sueoka-Aragane N, Nakamura T, Takeda Y, Mitsuoka M, Yamasaki F, et al. Co-existence of positive MET FISH status with EGFR mutation signifies poor prognosis in lung adenocarcinoma patients. Lung Cancer. 2012;75(1):89-94.

16. Chen YT, Chang JW, Liu HP, Yu TF, Chiu YT, Hsieh JJ, et al. Clinical implications of high MET gene dosage in non-small cell lung cancer patients without previous tyrosine kinase inhibitor treatment. J Thoracic Oncol. 2012;7(2):340-7.

17. Dziadziuszko R, Wynes MW, Singh S, Asuncion BR, Ranger-Moore J, Konopa $\mathrm{K}$, et al. Correlation between MET gene copy number by silver in situ hybridization and protein expression by immunohistochemistry in non-small cell lung cancer. J Thorac Oncol. 2012;7(2):340-7.

18. Xu L, Kikuchi E, Xu C, Ebi H, Ercan D, Cheng KA, et al. Combined EGFR/MET or EGFR/HSP9O inhibition is effective in the treatment of lung cancers codriven by mutant EGFR containing T790M and MET. Cancer Res. 2012;72(13):3302-11.

19. Spigel DR, Ervin TJ, Ramlau R, Daniel DB, Goldschmidt JH, Blumenschein GR, et al. Final efficacy results from OAM4558g, a randomized phase II study evaluating MetMAb or placebo in combination with erlotinib in advanced NSCLC. J Clin Oncol. 2011;29(suppl; abstr 7505).

20. Spigel DR, Edelman MJ, O'Byrne K, Paz-Ares L, Shames DS, Yu W, et al. Onartuzumab plus erlotinib versus erlotinib in previously treated stage IIIb or IV NSCLC: results from the pivotal phase III randomized, multicenter, placebo-controlled METLung (OAM4971g) global trial. J Clin Oncol. 2014;32(suppl; abstr 8000):5s.

21. Sequist LV, von Pawel J, Garmey EG, Akerley WL, Brugger W, Ferrari D, et al. Randomized phase II study of erlotinib plus tivantinib versus erlotinib plus placebo in previously treated non-small-cell lung cancer. J Clin Oncol. 2011;29(24):3307-15.

\section{Submit your next manuscript to BioMed Central and take full advantage of:}

- Convenient online submission

- Thorough peer review

- No space constraints or color figure charges

- Immediate publication on acceptance

- Inclusion in PubMed, CAS, Scopus and Google Scholar

- Research which is freely available for redistribution 